\title{
Kondisi Psikologi, Sosial, dan Spiritual pada Orang dengan HIV/AIDS Selama Pengobatan Antiretroviral di Komisi Penanggulangan AIDS Kota Bogor Tahun 2019
}

\author{
Ervan Meidan Ariatama, ${ }^{1}$ Titik Respati, ${ }^{2}$ Eka Nurhayati ${ }^{2}$ \\ ${ }^{1}$ Program Studi Pendidikan Dokter, ${ }^{2}$ Bagian Ilmu Kesehatan Masyarakat \\ Fakultas Kedokteran Universitas Islam Bandung,
}

\begin{abstract}
Abstrak
Penyakit HIV/AIDS selain mengakibatkan dampak kesehatan dapat juga mengakibatkan dampak negatif terhadap psikologi, sosial, dan spiritual pada kualitas hidup orang dengan HIV/AIDS (ODHA). Antiretroviral (ARV) merupakan obat penghambat proses replikasi HIV yang merupakan solusi untuk meningkatkan kualitas hidup dan harapan hidup penderita. Tujuan penelitian ini adalah menggambarkan kondisi psikologi, sosial, dan spiritual ODHA selama menjalani pengobatan ARV di Komisi Penanggulangan AIDS (KPA) Kota Bogor periode bulan Agustus-September 2019. Penelitian ini dilakukan menggunakan metode observasi analitik dengan pendekatan cross sectional. Data diambil menggunakan kuesioner World Health Organization Quality of Life-HIV Instrument (WHOQOL-HIV Instrument) yang terdiri atas 120 pertanyaan dan terbagi menjadi 6 domain (psikologi, sosial, spiritual, fisik, lingkungan hidup, dan tingkat kebebasan). Pada penelitian ini hanya diambil 3 domain, yaitu psikologi, sosial, dan spiritual dengan jumlah pertanyaan 52 butir yang dibagikan kepada 80 responden dan dilaksanakan selama bulan Agustus sampai bulan September 2019. Teknik pengambilan sampel menggunakan non-probability sampling jenis consecutive sampling berdasar atas rumus besar estimasi proporsi dengan presisi absolut. Hasil menunjukkan mayoritas kondisi psikologi, sosial, dan spiritual ODHA selama pengobatan antiretroviral di KPA Kota Bogor tahun 2019 dalam kondisi baik dengan persentase kondisi psikologi 96\%, sosial 99\%, dan spiritual 70\%. Simpulan penelitian ini adalah kondisi psikologi, sosial, dan spiritual pada ODHA di Komisi Penanggulangan AIDS Kota Bogor tahun 2019 mayoritas dalam kondisi baik, walaupun kondisi spiritual ODHA masih terdapat hasil kurang baik.
\end{abstract}

Kata kunci: Antiretroviral, HIV/AIDS, psikologi, sosial, spiritual

\section{Psychological, Social, and Spiritual Conditions in People Living with HIV/AIDS During Antiretroviral Treatment at the AIDS Prevention Commission at Bogor City in 2019}

\begin{abstract}
Apart from having an impact on health, HIV/AIDS can also have a negative psychological, social, and spiritual impact on people living with HIV/AIDS (PLWHA). Antiretroviral (ARV) as drugs that inhibits the process of replication of HIV, which is a solution to improve the quality of life and life expectancy of patients. The purpose of this study was to describe the psychological, social, and spiritual conditions of PLWHA during ARV treatment at the AIDS Prevention Commission in Bogor City in August to September 2019. The study was a cross-sectional study. The research material consisted of primary data taken using the World Health Organization-Quality Instrument HIV questionnaire (WHOQOL-HIV Instrument) consisting of 120 questions and divided into six domains (psychological, social, spiritual, physical, environment, degree of freedom). However, in this study, only three domains studied, which are psychological, social, and spiritual, with 52 questions and then distributed to 80 respondents and carried out from August to September. The sampling technique uses non-probability sampling type consecutive sampling based on large formula of proportion estimation with absolute precision. Results showed the psychological, social, and spiritual condition of PLWHA during antiretroviral treatment at the Bogor City AIDS Commission in 2019 shows a good condition. The majority of good psychological, social, and spiritual domain experienced by $96 \%, 99 \%$, and $70 \%$ of respondents, respectively. The conclusion of this research is the psychological, social, and spiritual conditions of PLWHA in the Bogor AIDS prevention commission in 2019 in the good conditions, even though there was a spiritual condition of ODHA that was still not good.
\end{abstract}

Keywords: Antiretroviral, HIV/AIDS, psychological, social, spiritual

Received: 26 January 2020; Revised: 14 July 2020; Accepted: 30 July 2020; Published: 31 July 2020

Koresponden: Ervan MeidanAriatama. Program Studi Pendidikan Dokter, Fakultas Kedokteran, Universitas Islam Bandung, Jl. Hariangbanga No.2, Hp: 0813221149333 Email: ervanmaa33@gmail.com 


\section{Pendahuluan}

Penyakit HIV/AIDS di beberapa negara Asia termasuk Cina, Indonesia, dan Vietnam menunjukkan epidemiologi yang jauh dari selesai dan jumlah orang yang terinfeksi penyakit ini terus berkembang. ${ }^{1}$ Laporan dari 514 kabupaten/Kota di 34 provinsi Indonesia menyatakan bahwa provinsi dengan jumlah infeksi HIV/AIDS tertinggi sampai tahun 2018 adalah DKI Jakarta sebanyak 55.099 orang, diikuti Jawa Timur sebanyak 43.399 orang, Jawa Barat sebanyak 31.293 orang, Papua sebanyak 30.699 orang, dan Jawa Tengah sebanyak 24.757 orang. $^{2}$

Pada tahun 2017 di Kota Bogor terdapat 532 orang terinfeksi HIV dan menempati urutan ketiga sebagai Kota/kabupaten dengan jumlah kasus HIV terbanyak setelah Kota Bandung dan Kota Bekasi. ${ }^{3}$ Orang dengan HIV/AIDS (ODHA) di Kota Bogor dipimpin, dikelola, dipantau, dan dievaluasi oleh Komisi Penanggulangan AIDS (KPA) Kota Bogor yang menjalankan tugasnya berdasar atas Keputusan WaliKota Bogor Nomor 443.2.45-176 Tahun 2014. Komisi Penanggulangan AIDS juga bertugas dalam mengadakan kerja sama regional dalam rangka penanggulangan AIDS, mendorong terbentuk kelompok peduli HIV/AIDS, dan menyampaikan laporan kepada KPA Nasional. ${ }^{4}$

Infeksi HIV/AIDS tidak hanya menimbulkan masalah bagikesehatan, tetapijuga dapat menimbulkan masalah terhadap kondisi sosial, ekonomi, dan psikologis. Secara alamiah hubungan sosial ODHA akan berubah karena mereka mengalami hambatan dalam interaksi sosial bersama keluarga, sahabat, rekan kerja, relasi, dan tetangga sekitar. Perubahan interaksi sosial tersebut dapat menimbulkan hal positif maupun negatif terhadap setiap penderita. ${ }^{5}$

Infeksi HIV/AIDS juga dapat menyebabkan permasalahan spiritual bagi penderitanya. Orang yang mengalami masalah spiritual akibat HIV/ AIDS biasanya selalu menyalahkan Tuhan, menolak beribadah, beribadah tidak sesuai dengan ketentuan, maka mengalami gangguan dalam beribadah dan distress spiritual. ${ }^{6}$

Hingga sekarang ini HIV/AIDS belum dapat disembuhkan karena belum ada obat yang dapat menghilangkan virus HIV di dalam tubuh penderita. Salah satu cara menurunkan infeksi HIV/AIDS, yaitu dengan penggunaan obat antiretroviral (ARV) yang telah diakui dunia sebagai obat penghambat proses replikasi HIV yang menyerang sistem kekebalan tubuh manusia. Pengobatan ARV hanya bersifat menghambat virus agar penderita dapat meningkatkan kualitas hidup dan meningkatkan harapan hidup. ${ }^{7}$

Tujuan penelitian ini adalah menggambarkan kondisi psikologi, sosial, dan spiritual ODHA selama pengobatan ARV di Komisi Penanggulangan AIDS Kota Bogor tahun 2019.

\section{Metode}

Penelitian ini merupakan penelitian observasi analitik dengan pendekatan cross sectional yang dilakukan di Komisi Penanggulangan AIDS Kota Bogor selama Agustus -September tahun 2019. Pengambilan sampel dilaksanakan pada bulan Agustus sampai dengan
September 2019 menggunakan kuesioner World Health Organization Quality of Life-HIV Instrument (WHOQOL-HIV Instrument) yang terdiri atas 120 pertanyaan dan terbagi menjadi 6 domain (psikologi, sosial, spiritual, fisik, lingkungan hidup, dan tingkat kebebasan). Pada penelitian ini hanya diambil 3 domain, yaitu psikologi, sosial, dan spiritual dengan jumlah pertanyaan 52 nomor yang dibagikan kepada 80 responden. Sampel penelitian ini adalah ODHA yang sedang melaksanakan pengobatan ARV di Komisi Penanggulangan AIDS Kota Bogor yang dapat membaca maupun menulis dan tidak mengalami gangguan psikiatri berat. Pengambilan sampel menggunakan non-probability sampling jenis consecutive sampling berdasar atas rumus besar estimasi proporsi dengan presisi absolut.

Penelitian ini sudah mendapat persetujuan etik dari Komite Etik Penelitian Kesehatan Fakultas Kedokteran Universitas Islam Bandung dengan Nomor: 127/Komite Etik.FK/IV/2019.

\section{Hasil}

Pada penelitian ini ditemukan karakterisitik reponden yang ada di Komisi Penanggulangan AIDS Kota Bogor yang menunjukkan bahwa laki-laki merupakan responden paling banyak dengan jumlah 47 orang, sedangkan responden perempuan berjumlah 33 orang. Responden laki-laki pada penelitian ini mayoritas berusia 21-29 tahun (51\%), sementara responden perempuan mayoritas berusia 30-39 tahun (61\%). Terdapat responden yang telah berusia $\geq 50$ tahun sebanyak 1 orang laki-laki.

Responden laki-laki dan perempuan mayoritas memiliki status HIV bergejala dengan persentase 54\% yang terdiri atas 24 laki-laki dan 19 perempuan. Terdapat 11 responden (14\%) yang telah memasuki fase AIDS yang terdiri atas 9 orang laki-laki dan 2 orang perempuan.

Lama durasi pengobatan antiretroviral responden berkisar antara tahun yang sama atau kurang dari 1 tahun sampai 19 tahun. Mayoritas responden memiliki durasi pada tahun yang sama atau kurang dari 1 tahun dengan persentase $14 \%$ dan terdapat $13 \%$ telah menjalani pengobatan antiretroviral selama 1 tahun setelah mereka di diagnosis positif HIV. Terdapat 2 orang responden laki-laki yang sudah melaksanakan pengobatan antiretroviral dengan durasi yang cukup panjang, yaitu selama 19 tahun (2\%) setelah pertama kali didiagnosis positif HIV.

Kondisi psikologi dan sosial pada responden di Komisi Penanggulangan AIDS Kota Bogor mayoritas menunjukkan hasil yang baik dengan persentase kondisi psikologi 96\% dan kondisi sosial 99\%. Pada kondisi spiritual menunjukkan hasil yang sama dengan kondisi yang lain, yaitu mayoritas kondisi spiritual baik (70\%) dan 30\% kondisi spiritual kurang baik. Jumlah tersebut cukup signifikan dibanding dengan kondisi kurang baik pada psikologi yang hanya 4\% dan kondisi sosial hanya $1 \%$. 
Tabel 1 Karakteristik Subjek Penelitian

\begin{tabular}{|c|c|c|c|c|c|c|}
\hline \multirow[t]{2}{*}{ Variabel } & \multicolumn{2}{|c|}{$\begin{array}{l}\text { Laki-laki } \\
(n=47)\end{array}$} & \multicolumn{2}{|c|}{$\begin{array}{c}\text { Perempuan } \\
\quad(n=33)\end{array}$} & \multirow{2}{*}{$\begin{array}{l}\text { Jumlah } \\
(\mathbf{n}=\mathbf{8 0})\end{array}$} & \multirow{2}{*}{$\%$} \\
\hline & $\mathbf{n}$ & $\%$ & $\mathbf{n}$ & $\%$ & & \\
\hline \multicolumn{7}{|l|}{ Usia (tahun) } \\
\hline $21-29$ & 24 & 51 & 8 & 24 & 32 & 40 \\
\hline $30-39$ & 11 & 23 & 20 & 61 & 31 & 39 \\
\hline $40-49$ & 11 & 24 & 5 & 15 & 16 & 20 \\
\hline$>50$ & 1 & 2 & $\mathrm{O}$ & $\mathrm{o}$ & 1 & 1 \\
\hline \multicolumn{7}{|l|}{ Status HIV } \\
\hline Tidak bergejala & 14 & 30 & 12 & 36 & 26 & 32 \\
\hline Bergejala & 24 & 51 & 19 & 58 & 43 & 54 \\
\hline AIDS & 9 & 19 & 2 & 6 & 11 & 14 \\
\hline \multicolumn{7}{|l|}{$\begin{array}{l}\text { Durasi } \\
\text { Pengobatan } \\
\text { Antiretroviral }\end{array}$} \\
\hline Tahun yang sama & 7 & 15 & 4 & 12 & 11 & 14 \\
\hline 1 tanun & 9 & 19 & 1 & 3 & 10 & 13 \\
\hline 2 tahun & 3 & 6 & 3 & 9 & 6 & 7 \\
\hline 4 tahun & 3 & 6 & 4 & 12 & 7 & 9 \\
\hline 4 tanun & 3 & 6 & 3 & 9 & 6 & 7 \\
\hline 6 tahun & 2 & 4 & 1 & 3 & 3 & 4 \\
\hline 8 tanun & 3 & 6 & 4 & 12 & 7 & 9 \\
\hline 10 tahun & $\mathrm{O}$ & $\mathrm{O}$ & 5 & 15 & 5 & 6 \\
\hline 10 tanun & 3 & 6 & 3 & 9 & 6 & 7 \\
\hline $\begin{array}{l}11 \text { tahun } \\
12 \text { tahun }\end{array}$ & 4 & 8 & 1 & 3 & 5 & 6 \\
\hline 13 tahun & O & $\mathrm{O}$ & 1 & 3 & 1 & 1 \\
\hline 13 tahun & 3 & 6 & 2 & 6 & 5 & 6 \\
\hline $\begin{array}{l}14 \text { tahun } \\
15 \text { tahun }\end{array}$ & 1 & 2 & 1 & 3 & 2 & 2 \\
\hline 17 tahun & 1 & 2 & o & o & 1 & 1 \\
\hline 18tahun & 2 & 4 & $\mathrm{O}$ & o & 2 & 2 \\
\hline 18 tanun & 1 & 2 & $\mathrm{O}$ & $\mathrm{O}$ & 1 & 1 \\
\hline 19 tanun & 2 & 4 & $\mathrm{O}$ & o & 2 & 2 \\
\hline
\end{tabular}

Tabel 2 Kondisi Psikologi, Sosial, dan Spiritual Responden

\begin{tabular}{|c|c|c|c|c|c|c|}
\hline \multirow{2}{*}{ Kondisi } & \multicolumn{2}{|c|}{$\begin{array}{c}\text { Laki-laki } \\
(n=47)\end{array}$} & \multicolumn{2}{|c|}{$\begin{array}{c}\text { Perempuan } \\
(n=33)\end{array}$} & \multirow{2}{*}{$\begin{array}{r}\text { Jumlah } \\
-(\mathbf{n}=\mathbf{8 0})\end{array}$} & \multirow[t]{2}{*}{$\%$} \\
\hline & $\mathbf{n}$ & $\%$ & $\mathbf{n}$ & $\%$ & & \\
\hline \multicolumn{7}{|l|}{ Psikologi } \\
\hline Kurang baik & 2 & 4 & 1 & 3 & 3 & 4 \\
\hline Baik & 45 & 96 & 32 & 97 & 77 & 96 \\
\hline \multicolumn{7}{|l|}{ Sosial } \\
\hline Kurang baik & 1 & 2 & o & $\mathrm{O}$ & 1 & 1 \\
\hline Baik & 46 & 98 & 33 & 100 & 79 & 99 \\
\hline \multicolumn{7}{|l|}{ Spiritual } \\
\hline Kurang baik & 13 & 28 & 11 & 33 & 24 & 30 \\
\hline Baik & 34 & 72 & 22 & 67 & 56 & 70 \\
\hline
\end{tabular}

\section{Pembahasan}

Berdasar atas data yang diperoleh dari penelitian ini didapatkan bahwa responden terbanyak di Komisi Penanggulangan AIDS (KPA) Kota Bogor tahun 2019, yaitu laki-laki 47 orang. Hasil ini sama dengan penelitian di Sumba Timur Provinsi Nusa Tenggara Timur dan penelitian di RSUD DR. Soetomo Surabaya bahwa penderita HIV/AIDS paling banyak pada lakilaki dibanding dengan perempuan..$^{8,9}$ Hal tersebut sesuai dengan data Ditjen PP \& PL Kemenkes RI tahun 2014 bahwa pola penularan HIV/AIDS berdasar atas jenis kelamin di Indonesia memiliki pola yang sama dari tahun 2008-2014 dengan angka kejadian paling banyak pada laki-laki dibanding dengan perempuan. ${ }^{10}$ Hal tersebut terjadi karena perilaku perempuan lebih baik dibanding dengan laki-laki, terutama dalam melakukan faktor risiko seperti hubungan seksual dengan lawan jenis maupun sesama jenis, penggunaan narkoba suntik, dan faktor risiko lainnya yang berpotensi menimbulkan penularan HIV/AIDS. ${ }^{8}$

Status HIV pada responden ODHA di KPA Kota Bogor yang sedang menjalankan pengobatan ARV mayoritas dalam kondisi bergejala dengan jumlah 43 orang (54\%), kemudian sebanyak 26 orang (32\%) masih dalam fase tidak bergejala, dan sebanyak 11 orang (14\%) sudah memasuki status AIDS. Penelitian ini sejalan dengan penelitian Lindayani ${ }^{11}$ di Kota Bandung yang menyatakan bahwa ODHA yang sedang melaksanakan pengobatan ARV kebanyakan dalam status bergejala dengan persentase $81 \%$.

Durasi pengobatan antiretroviral pada ODHA di KPA Kota Bogor tahun 2019 berkisar antara tahun yang sama atau kurang dari satu tahun sampai 19 tahun. Secara keseluruhan, 11 orang dari 80 responden (14\%) memiliki durasi pengobatan antiretroviral pada tahun yang sama atau kurang dari 1 tahun dan (13\%) orang lainnya memiliki durasi pengobatan antiretroviral selama 1 tahun. Terdapat (2\%) responden ODHA memiliki durasi pengobatan antiretroviral cukup lama, yaitu selama 19 tahun. Penelitian ini memiliki kesamaan dengan penelitian yang dilakukan di poli Cendana RSUD Ngudi Waluyo Wlingi Kota Blitar bahwa lama pengobatan ARV pada ODHA mayoritas dalam waktu kurang dari 1 tahun atau tahun yang sama setelah didiagnosis positif HIV. ${ }^{2}$ Pada penelitian di Surakarta bahwa ODHA yang telah menjalani terapi lebih dari 29 bulan memiliki kualitas hidup yang lebih baik. Hal tersebut terjadi karena secara fisik, pasien yang telah melaksanakan terapi ARV dapat menjalani aktivitas sehari-hari seperti orang yang tidak menderita HIV/AIDS. Infeksi HIV/AIDS dapat disebut sebagai penyakit yang dapat dikendalikan dengan terapi ARV. ${ }^{13}$

Kondisi psikologi orang dengan HIV/AIDS selama pengobatan antiretroviral di KPA Kota Bogor tahun 2019 menunjukkan hasil yang baik, yaitu 96\% dan kurang baik 4\%. Penelitian ini sejalan dengan penelitian di RSUD Ngudi Waluyo Wlingi Kota Blitar bahwa sebagian besar ODHA dalam kondisi yang baik, walaupun masih ada ODHA yang kondisi psikologisnya kurang baik. ${ }^{14}$ Penelitian yang dilakukan di Makassar menunjukkan hasil yang berbeda, penelitian tersebut menjelaskan bahwa kondisi psikologi pada ODHA mayoritas menunjukkan hasil yang kurang baik dengan 
persentase $76,2 \%$. Penelitian tersebut juga menyatakan bahwa ODHAyang mengalami kondisi psikologi kurang baik akibat sering merasakan feeling blue (kesepian, putus asa, cemas, dan depresi), hal-hal yang bersifat negatif, dan kurang mengikuti arahan konselor untuk mengonsumsi ARV secara rutin sehingga memasuki tahap AIDS yang dapat memengaruhi kondisi psikologisnya. Penelitian di LSM Perjuangan Kupang menjelaskan bahwa kondisi psikologi ODHA yang baik disebabkan oleh saling dukungan antara sesama ODHA laki-laki maupun perempuan dalam kelompok dukungan sebaya sehingga dapat mengurangi tekanan psikologis yang dialami ODHA karena mereka tidak merasa sendiri dalam menjalani hidup dengan kondisi tubuh terinfeksi HIV/AIDS.

Selama pengobatan antiretroviral, ODHA di KPA Kota Bogor mayoritas sudah menunjukkan kondisi yang baik pada kondisi sosialnya, yaitu sekitar 99\%. Penelitian ini sejalan dengan penelitian Lindayani ${ }^{11} \mathrm{di}$ Kota Bandung yang menyatakan bahwa ODHA yang sedang melaksanakan pengobatan ARV cenderung memiliki kondisi sosial yang baik dibanding ODHA yang tidak melaksanakan pengobatan ARV. Hal tersebut terjadi karena selama menjalani pengobatan ARV dengan kelompok dukungan sebaya, mereka merasa memiliki keluarga baru yang dapat ditemani untuk berbagi suka dan duka sehingga mereka dapat memperoleh dukungan sosial dari sesama ODHA yang tergabung di kelompok tersebut dan dapat membuat kondisi sosial ODHA tersebut menjadi lebih baik. Penelitian di Kota Makassar menunjukkan hasil yang berbeda, bahwa kondisi sosial kurang baik merupakan kondisi yang paling banyak dirasakan oleh ODHA. Orang dengan HIV/AIDS yang mengalami kondisi sosial kurang baik disebabkan oleh selama mereka menjalani pengobatan ARV merasa dikucilkan oleh teman maupun keluarga sendiri dan mereka menganggap bahwa masalah terbesar yang dihadapi adalah ketika mereka diisolasi dalam hubungan sosial dengan masyarakat sekitar, teman, maupun keluarga sendiri. Penelitian di LSM Perjuangan Kupang menjelaskan bahwa dukungan sosial sangat berpengaruh terhadap kualitas hidup ODHA terutama dalam aspek kondisi sosial.

Kondisi spiritual ODHA di KPA Kota Bogor selama pengobatan ARV pada tahun 2019 menunjukkan hasil yang baik dengan persentase $70 \%$. Jumlah responden dengan kondisi spiritual kurang baik menunjukkan angka yang cukup besar dibanding dengan kondisi kurang baik pada psikologi dan spiritual. Hasil penelitian ini memiliki kesamaan dengan penelitian sebelumnya di Kota Makassar bahwa kondisi spiritual yang baik lebih banyak dibanding dengan kondisi spritual yang tidak baik. Hal tersebut diakibatkan oleh ODHA di Kota Makassar selalu melakukan ibadah dan lebih mendekatkan diri dengan Tuhan pada saat mereka merasa khawatir akan masa depan yang akan datang dan mereka menganggap bahwa ketika dirinya mendekatkan diri dengan Tuhan maka akan terasa lebih tenang, terutama tentang kematian.

\section{Simpulan}

Kondisi psikologi dan sosial ODHA selama pemberian obat ARV di Komisi Penanggulangan AIDS Kota Bogor tahun 2019 mayoritas menunjukkan hasil yang baik. Kondisi spiritual secara umum menunjukkan hasil yang baik.

\section{Ucapan Terima Kasih}

Ucapan terima kasih ditujukan kepada H. Iwan Suryawan S.Sos selaku ketua Komisi Penanggulangan AIDS Kota Bogor dan ibu Siti Suginati beserta jajaran staf Komisi Penanggulangan AIDS Kota Bogor. Terima kasih kepada teman-teman ODHA di Komisi Penanggulangan AIDS Kota Bogor yang telah bersedia untuk dijadikan responden pada penelitian ini.

\section{Daftar Pustaka}

1. Ruxrungtham K, Brown T, Phanuphak P. HIV/ AIDS in Asia. Lancet. 2004 Jul 3-9;364(9428):6982. doi: 10.1016/So140-6736(04)16593-8.

2. Kementerian Kesehatan Republik Indonesia [Internet]. [diunduh 28 Januari 2019]. Tersedia dari: http://www.depkes.go.id/article/ view/18120300001/hari-aids-sedunia-momenstop-penularan-hiv-saya-berani-saya-sehat-.html

3. Kemenkes RI. Laporan perkembangan HIV/AIDS dan infeksi menular seksual (IMS) triwulan IV tahun 2017. Jakarta: Kemenkes RI; 2018.

4. KPA Kota Bogor. Situasi HIV di Kota Bogor. Bogor: KPA Kota Bogor; 2018.

5. Pradita DPY, Sudibia IK. Analisis dampak sosial, ekonomi, dan psikologis penderita HIV AIDS di Kota denpasar. J Bul Stud Ekon. 2014;19(2):1939.

6. Tanjung DM. Karakteristik distress spiritual pada orang dengan HIV/AIDS (ODHA) di RSUP Haji Adam Malik Medan. 2016 Dec 19 [diunduh 20 Jan uari 2019]: Tersedia dari: http://repository.usu. ac.id/handle/123456789/63305

7. ILO, WHO. Pedoman bersama ILO/WHO tentang pelayanan kesehatan dan HIV/AIDS. Jakarta: Direktorat Pengawasan Kesehatan Kerja; 2005.

8. Nyoko YO, Hara MK, Abselian UP. Karakteristik penderita HIV/AIDS di Sumba Timur tahun 2010-2016. J Kesehat Prim. 2016;1:4-15.

9. Unzila SR, Nadhiroh SR, Triyono EA. Hubungan kepatuhan antiretroviral therapy (ART) satu bulan terakhir dengan kualitas hidup pasien HIV/ AIDS di RSUD DR. Soetomo Surabaya. Media Gizi Indones. 2016;11(1):24-31.

10. Kemenkes RI. Situasi dan analisis HIV AIDS. Jakarta: Kemenkes RI; 2014.

11. Lindayani L. Studi kompratif: kualitas hidup klien HIV (+) yang menggunakan dan tidak menggunakan antiretroviral therapy di Bandung. J Pendidik Keperawatan Indones. 2016;2:137-45. 
12. Setiyorini E. Gambaran kualitas hidup ODHA yang menjalani terapi antiretroviral (ARV) di Poli Cendana RSUD Ngudi Waluyo Wlingi. J Ners Kebidanan. 2015;2(1):6-14.

13. Mardia, Ahmad RA, Riyanto BS. Kualitas hidup orang dengan HIV/AIDS berdasar atas kriteria diagnosis dan faktor lain di Surakarta. J Community Med Public Heal. 2017;33:147-52.

14. Setiyorini E. Gambaran kualitas hidup ODHA yang menjalani terapi Antiretroviral (ARV) di poli Cendana RSUD Ngudi Waluyo Wlingi. J Ners Kebidanan. 2015;2(1):6-14. 